\title{
Social Media and Youth Ministry in Nigeria: Implications and Christological Thrust
}

\author{
David C. Ononogbu (Ph.D) ${ }^{1}$, Nathan Chiroma (Ph.D) ${ }^{2}$ \\ ${ }^{I}$ Department of Religion and Cultural Studies, Faculty of the Social Sciences, University of Nigeria \\ ${ }^{2}$ Pan Africa Christian University Nairobi, Kenya. Research Associate, Department of Practical Theology, \\ University of Stellenbosch South
}

*Corresponding Author: David C. Ononogbu (Ph.D), Department of Religion and Cultural Studies, Faculty of the Social Sciences, University of Nigeria

\begin{abstract}
Social media is driven technologically, rather than culturally. For many young people, engaging in social media activities is a routine that benefits them in that it enhances their communication, social connection and technical skills. The number of youths using social media platforms continues to increase and the statistics are overwhelming on how often they do so each day. By implication, a large part of this generation's social, emotional and even spiritual development takes place online. This paper argues that, in addition to its benefits, social media can also be a double-edged sword, impeding wholesome youth development and even fostering a dysfunctional youth generation. In other words, social media have the potential to make or mar and, therefore, can pose a major challenge to an effective youth ministry in Nigeria. Seemingly the Church is yet to devise effective strategies that will enable her to harness the limitless potential of social media with regard to reaching out to the youth. This paper seeks to bring out the experiences of young people through a documentary study with the goal of helping the church, youth ministry workers to a better working understanding of how to work with young people in various contexts. This paper will also provide key effective strategies that will enhance not only the technological advancement of young people, but to also equip the church to minister better to these young people. And lastly the paper will consider the Christological implications of the findings to effect youth ministry.
\end{abstract}

Keywords: Social Media, Youth, Youth Ministry, Christology.

\section{INTRODUCTION}

Young people generally live in two (in fact, three) worlds. The future belongs to them and they will take over the mantle of leadership at some point, yet they constantly hover between the past and the present. In much the same way, they are pulled back and forth by the conflicting messages, pressures and realities of these worlds. The result is that they are hardly ever prepared and equipped for the challenges of the future. More so, in contemporary society, Christian norms and values have declined, with moral relativity and extreme flexibility paving the way for the sweeping influence of social media value systems on youths. This is largely because social media continue to have a significant impact on culture, and young people are born into the digital age. In other words, they are constantly challenged by the moral crises around them and by the pressure to participate and find expression in the world of social media.

\footnotetext{
${ }^{1}$ David C. Ononogbu studied religion and society (sociology of religion) at the University of Nigeria. In 2005 and 2010 respectively, he earned his Master's and Ph.D degrees studying the youth, unemployment and the social responsibility of the church in Nigeria. He has researched widely and written extensively on the youth and youth-related issues and challenges in Nigeria, where he continues to research into the perception of the church on its role in addressing dysfunction among young people and the social issues confronting them. Currently, his interest lies in understanding the theological underpinnings of youth engagement or lack thereof by the church in Nigeria, amidst the pressure of global and local forces. David serves on the faculty of the University of Nigeria where he teaches the principles and models of contemporary youth profiling, peace and conflict and the basic and ethical principles of counselling

${ }^{2}$ Nathan H. Chiroma is a senior lecturer at Pan Africa Christian University. He holds a PhD in Practical Theology from the University of Stellenbosch in South Africa.
} 
In view of this, Ogunlesi ${ }^{3}$ asserts that social media are made up of neutral, passive participants in the drama of human existence. People come to these communication channels as they are and use them in several ways - including ways that were not intended by those who created these platforms. In his view, what is happening is similar to what has happened in the pharmaceutical industry, where a drug ends up being used for purposes other than for what it was originally developed or intended. By implication, this means that social media platforms in themselves are not designed to be negative or positive; rather, like any other tool, these platforms become good or bad, depending on who is using them and for what purposes they are being adopted.

Ogunlesi's view is somewhat simplistic, since the invention of a new technology often has the potential to change culture. In the case of social media, this is an apparent understatement given the incredible level and volume of connectivity it has brought among youths. More so, many young people get sucked into the social media web long before they even realise they actually have a choice to make. Indeed, there has always been a youth culture but social media now play a significant role in youth culture and afford young people the space and ability to function in a world where they are two or three steps ahead of most adults. In this world, Facebook, Twitter, Instagram, and WhatsApp enable particularly young people to express themselves in new ways. Their sources of information and knowledge are each other and not necessarily someone or something reliable or true, since they create their own reality without recourse to any other source and without even being fully aware of what they are doing.

Once a young person acquires a cell phone today all the applications necessary for social networking are available, but at the heart of all this, the problem is not necessarily the availability of an internet connection and accessibility. The essence of the problem is the content - that which is being accessed online - and the fact that there is absolutely no restriction on what is being downloaded and uploaded by youths. For instance, in addition to the benefits that are derived from a social media presence and activities, young people are exposed to immodest music, pornography and the use of vulgar terms and language. Consider the initialisms that young people currently use, such as IWSN, meaning "I want sex now", or GNOC: "get naked on camera". When a parent or adult becomes too inquisitive about what they say and do online, youths simply shut them out by notifying their friends with a clever initialism, PIR, meaning "parent in room". Table 1 below shows some more of these terms:

Table1. Initialisms used on social media and their meaning

\begin{tabular}{|l|l|l|l|l|l|}
\hline S/n & Term & Meaning & S/n & Term & Meaning \\
\hline 1 & $\mathbf{1 1 7 4}$ & Party meeting place & 2 & THOT & That hoe (whore) over there \\
\hline 3 & $\mathbf{9}$ & Parent watching & 4 & $\mathbf{9 9}$ & Parent gone \\
\hline 5 & CU46 & See you for sex & 6 & NIFOC & Naked in front of computer \\
\hline 7 & $\mathbf{5 3 X}$ & Sex & 8 & CID & Acid (the drug) \\
\hline 9 & Broken & Hungover from alcohol & 10 & $\mathbf{4 2 0}$ & Marijuana \\
\hline 11 & POS & Parent over shoulder & 12 & SUGARPIC & Suggestive or erotic photo \\
\hline 13 & KOTL & Kiss on the lips & 14 & $\mathbf{8}$ & Oral sex \\
\hline 15 & TDTM & Talk dirty to me & 16 & PRON & Porn \\
\hline 17 & (L)MIRL & Let's meet in real life & 18 & CD9 & Parents around/Code 9 \\
\hline 19 & IPN & I'm posting naked & 20 & LH6 & Let's have sex \\
\hline 21 & WTTP & Want to trade pictures? & 22 & DOC & Drug of choice \\
\hline 23 & GYPO & Get your pants off & 24 & KPC & Keeping parents clueless \\
\hline
\end{tabular}

Source: Wallace $^{4}$

The implication is that communication between two or more people by means of social media is instant over any distance, if a network and data are available, and even when this interaction appears to be innocuous, young people generally lose relevant social skills when they constantly escape the space around them and retreat into cyberspace, regardless of the time or where they are. Perhaps the biggest effect of these new media is on youths' social relationships. Moreover, young people often do not realise that, when they use social media, they leave a trail: a digital footprint. Hence, while they may establish healthy friendships and visit acceptable sites, they are also easy prey and may become

\footnotetext{
${ }^{3}$ T. Ogunlesi, How Nigerians Use Social Media, Premium Times, 28 September 2015.

${ }^{4}$ K. Wallace, “28 Internet Acronyms every Parent should know," last modified 9 January 2015, accessed 9

January 2016, http://edition.cnn.com/2014/12/08/living/internet-acronyms-every-parent-should-know/
} 
victims of sexting, pornography, and cyber-bullying, or may be recruited for terrorist cells and other anti-social behaviours and groups. Other possible negative outcomes include a lack of privacy, reduced learning and research abilities, reduction in real human contact and in writing skills, higher vulnerability to crime, emotional distress and anxiety, and severe isolation. Eventually, some of these young people slip into depression and if not helped in time, suicide may become an option for them to end it all.

Another aspect to the dilemma of youths and social media is that the Nigerian youth is a peculiar species, since Nigerian society continues to be marred by socio-cultural and political irregularities, such as economic collapse, deepening poverty, youth unemployment, non-functional and inadequate social amenities, infrastructural decay and the enormous negative influence of globalisation. More often than not, the youth is at the receiving and worst end of all these ills. ${ }^{5}$ First, they find it extremely difficult to understand the paradox of having to grovel under the burden of these enervating problems amidst the availability of so many human and natural resources. Second, there is a rich religious heritage in Nigeria that is being bequeathed to them and which many of them have come to embrace. Third, in the absence of any provision and/or direction from both the government and the Church, many youths find expression for their pent-up disappointment, frustration and anger through social media and other anti-social outlets. This is a potent dilemma, since social media are not just an escape mechanism for youths but a weapon with which to fight back - something with which they try to build resistance against the system.

\section{Clarifying The Terms}

\subsection{Christology}

Literally, meaning $\chi \rho i \sigma \tau o \varsigma \lambda o \gamma \omega \varsigma$ (Christos logos) i.e. 'Christ-words', Christology refers to the branch of Christian theology relating to the person, nature, and work of Christ. As a model for Christian ministry, it is concerned with the systematic presentation of the work of Christ through the total activities of the Church. In other words, in it the Church has a pattern with which to understand social realities and respond to them through the lens of the salvific work of Jesus. In this paper, therefore, Christology is used to capture the essence of God's relation to, concern for, and mission towards the redemption of human life and society as a model for the Church.

\subsection{Social Media}

This term refers to any online platform over which individuals and groups (corporate and informal) who share similar personal, career and other interests, activities and backgrounds connect and build social networks or relations with each other. Basically, ideas, interests, pictures, videos and information within the social media framework are created, exchanged and shared instantly, while leaving a digital footprint behind.

\subsection{Youth}

Young people are not a homogenous group in Nigeria, but generally speaking, the youth stage refers to the period of human life between childhood and maturity. A typical youth is characteristically resourceful, optimistic, adventurous, energetic and bold, as well as fearless, willful and gullible. In this paper, 'youth' refers to a person in the period of physical and psychological development between 20 and 35 years of age. Youth ministry refers to the age-specific and strategic efforts of the Church to identify and support young people in their journey of life, both personally and spiritually. It therefore entails the targeted response of the Church to the challenges of the youths. In this paper 'young people' and 'youths' are used interchangeably.

\section{THE YOUTH AND SOCIAL MEDIA TRENDS IN NigERIA}

Over the past few years, social media have picked up steam and are thriving. Markley ${ }^{6}$ posits that the combination of social media and mobile internet is a technological revolution that has led to a

\footnotetext{
${ }^{5}$ D. C. Ononogbu, "The Youth and Mission in the Mainline Churches: Between Worship and Development in Nigeria" (paper presented at the International Conference on Theology and Development (ICTD) in Nigeria, March 2016).

${ }^{6}$ B. Markley, "Effects of New Media on Youth Ministry" (Senior Honours Theses, Paper 126, University of Maryland, 2015).
} 
changed culture and has drastically affected all generations, particularly generation $\mathrm{z}$, which includes anyone born after 1995. This is such that they have grown up in a world where they own smartphones, have access to the internet, and social media have become an integral part of their lives, since sites such as Facebook, Twitter and Instagram offer multiple daily opportunities for connecting with friends, classmates and people with shared interests.

Bartlett, Krasodomski-Jones, Daniel, Fisher and Jesperson ${ }^{7}$ posit that with a total of $186,410,197$ active mobile lines in Nigeria by February 2015, Nigeria has witnessed an exponential growth in internet usage. From a modest 200,000 users in 2000, now an estimated 51 per cent of the population use the internet and much of this increase is driven by the growth in mobile web access. The Mobile Africa 2015 study reports that 47 per cent of Nigerians use their phones to access the internet; and while Facebook penetration in Nigeria only stood at six per cent in 2014 (around 11 million users), the figure is rapidly growing. Hence, engaging in various forms of social media is a routine activity that research has shown to benefit youths in that it enhances online connection, communication and technical skills. ${ }^{8}$ Indeed, social media continue to expand and change with new applications appearing every day and with its ability to transform how people engage, sell, buy, create and live in the digital age. Aside from what is generally regarded as mainstream social media platforms (Facebook, Twitter, YouTube), Nigerians have a strong presence on platforms such as 2 go and Eskimi. ${ }^{9}$

Taking a different angle, the Broadcasting Board of Governors ${ }^{10}$ reports that awareness and use rates are much lower among older and less educated Nigerians; 51 per cent of those aged 35 or older have heard of social networking services but just 13 per cent of this age group said they used such a service in a week. Meanwhile, a 2015 study on social media users in Nigeria reports that the use of social networking sites was greater among men (70 per cent) than women ( 28 per cent); it equally found some correlation between levels of education and use of the internet or social media, and that younger people are the bulk of overall internet users in Nigeria. ${ }^{11,12}$

Two vital observations are paramount at this point. The first is that a large part of this generation's social, emotional and spiritual development takes place on the internet and while interacting on social media. The second is that in the world of social media anything goes - there are absolutely no restrictions. For instance, there are strong indications that young people are frequently exposed to online expressions of traditionally offline attitudes such as cyber-bullying, clique-forming, and sexual experimentation, ${ }^{13,14}$ privacy issues, and sexting. Other psycho-social problems include internet addiction and concurrent sleep deprivation. ${ }^{15}$ In view of this, because they generally have a limited

\footnotetext{
7 J. Bartlett, A. Krasodomski-Jones, N. Daniel, A. Fisher, and S. Jesperson, "Social Media for Election Communication and Monitoring in Nigeria" (prepared by Demos for the Department for International Development), last modified 2015, accessed 16 June, 2016, http://www.demos.co.uk/wpcontent/uploads/2015/11/Social-Media-in-Nigerian-Election.pdf

${ }^{8}$ M. Ito, H. Horst, and M. Bittani, "Living and Learning with New Media: Summary of Findings from the Digital Youth Project" (Chicago, IL, in John D. and Catherine T. MacArthur Foundation Reports on Digital Media and Learning), last modified 2008, accessed 16 June, 2016,

http://digitalyouth.ischool.berkeley.edu/files/report/digitalyouth-TwoPageSummary.pdf.

9 Africa Practice, "Social Media Landscape in Nigeria," last modified 2014, accessed 16 June 2016, http://www.africapractice.com/wp-content/uploads/2014/04/Africa-PracticeSocial-Media-Landscape-Vol-1.pdf

${ }^{10}$ Broadcasting Board of Governors, "Contemporary Media Use in Nigeria," last modified 2014, retrieved 24 April 2016, https://www.bbg.gov/wp-content/media/2014/05/Nigeria-research-brief.pdf

${ }^{11}$ R. Berry, "Older People and the Internet: Towards a 'System Map' of Digital Exclusion," International Longevity Centre, UK, last modified 2011, accessed 24 April 2016, http://www.ilcuk.org.uk/files/pdf _pdf_181.pdf

${ }^{12}$ R. Ciboh. "Adult Users' Engagement and Utilisation of Social Network Sites in Nigeria” (paper presented at the International Conference on Communication, Media, Technology and Design, Dubai, United Arab Emirates, 16-18 May 2015).

13 A. Lenhart, "Teens and Sexting," Washington, DC: Pew Research Centre, last modified 2010, accessed 4 August 2016, http://pewinternet.org/Reports/2009/Teens-and-Sexting.aspx

${ }^{14}$ J. W. Patchin and S. Hinduja, "Bullies move beyond the Schoolyard: A Preliminary look at Cyberbullying," Youth Violence Juv Justice, 4(2) (2006):153.

15 D. A. Christakis and M. A. Moreno, "Trapped in the Net: Will Internet Addiction become a 21st-Century Epidemic?” Paediatric Adolescent Med. 163(10) (2009).
} 
capacity for self-regulation and high vulnerability to peer pressure, young people are often at risk as they navigate and experiment with social media.

\section{IMPACT AND IMPLICATIONS OF SOCIAL MEDIA ON YOUTH MINISTRY IN NigERIA}

Current youth culture is completely different from what it had been a decade ago, and social media play a significant role in this emerging culture. In addition to expressing themselves in new ways by means of social media, young people generally escape the space around them and retreat into cyberspace regardless of time or place. This behaviour has created three significant challenges: the loss of relevant interpersonal skills; the loss of privacy and individual identity; and exposure to repulsive and often corrupting content and influences.

With regard to the first challenge, the loss of interpersonal skills, social media have undoubtedly made information sharing more efficient, and youth ministers themselves now use these platforms to advance their programmes and communicate with their youths. However, the downside is that social media diminish the capacity to develop and sustain interpersonal interaction with others, and the communication skills of several youths are eroded by the lengthy period of time spent on these platforms. Thus, what is actually possible via social media is connection in contrast to interaction, since such platforms make it easier for users to connect but harder to interact in a personal way. On the whole, the existence of an accessible plethora of online relationships has made it challenging for many youths to develop face-to-face relationships and have actual conversations. As a result, the idea of physical togetherness is being broken down and replaced with a new kind of virtual togetherness.

Second, the imposing nature of social media is destroying individual identity and self-esteem. Young people get the impression that they are known and loved, listened to and cared for via these platforms, which is why they do shocking things while connected on social media. This is how they virtually replace or regain the love, protection and support that they are denied at home and in society. By implication, this usually happens when they lose the sense of self identity and feel that they have nothing to lose - therefore they look outward for affirmation, for belonging and for someone to listen to them. This is also why it is harder to develop a deeper relationship with most youths today even though it is much easier to contact and connect with them via these platforms.

Third, with the loss of interpersonal skills and with little or no self-esteem, the slide into promiscuity and crime appears to be inevitable. So many youths are building social relationships in new, harmful ways - by means of sexting, nudity, pornography, online harassment and cyber-bullying as well as initiation and recruitment into negative self- and social-destructive behaviours and groups. Many of them are social media victims caught in a maze that is beyond their scope of comprehension and experience, a state of affairs that challenges the essence of having a youth ministry, and shows partial defeat on the part of the Church.

Even though some adults use technology well and are comfortable with and capable of holding their own in the world of social media, they still find it difficult to catch up with the digitally savvy youths in general for several reasons. Older adults tend to lack a basic understanding of the new forms of socialisation, which are integral to the lives of youths; and they do not have adequate technical abilities or the time required to keep pace with them in the ever-changing social media landscape. In addition, they often lack the basic understanding that young people's online lives have grown to become an extension of their offline lives. Consequently, there is a knowledge and technical skills gap between most adults and youths, which leads to a disconnection in how they participate in the online world.

On the part of the Church, most youth ministries are ill-equipped to effectively minister to young people because the Church has no idea of the types of music and language young people are exposed to on social media. And although these ministries deal with several issues that arise out of social media activities every day, many ministries lack the capacity to truly minister to youths about these issues. In all of this inadequacy, the core challenge is ministries' inability to show youths how to have a social media presence and navigate the emotional hazards and moral conflicts that confront them. The outcome is that when young people are bullied, abused and/or recruited online, youth ministers and ministries are not privy to those experiences, exposures and traumas until weeks, months and even years later when the wounds have become festering or the scars are indelible. 


\section{Christological Thrust FOR YOUTH Ministries IN Nigeria}

In Christology the church has a pattern for mission and ministry in society. With particular reference to youth ministry, the challenge is to interpret the situation correctly and engage the challenges in ways that are relevant and essential to youth realities today.

A most remarkable man confronts us in Jesus Christ. In Jesus we find the model of a well-rounded youth (Lk. 2: 52), a man of prayer who had a deep relationship with God (Lk. 5: 16), a man with a profound sense of mission and a real vision for his own life and ministry (Jn. 4: 34; 9; 4-5). He was courageous enough to challenge the system, yet a man of love, compassion and forgiveness. Jesus reached out to the outcast; He loved the vulnerable and the poor and brought healing to those who were hurting. Ultimately, $\mathrm{He}$ revealed God to the world because compassion was the defining benchmark of his life and ministry.

Against this backdrop, the Church has a salient pattern in Jesus's life and cannot afford to be an island. Markley ${ }^{16}$ asserts that technology and religion have been intertwined for centuries. For instance, when Johannes Gutenberg developed the metal-type press in the late 1430s, the first book that was printed with this world-changing invention was the 42-line Gutenberg Bible. Again, when Martin Luther wrote the 95 theses, challenging certain policies of the Church in Germany and Europe as a whole, the Protestant Reformation spread like wildfire. And this was made possible because copies of Luther's writings were published and publicised in a short time span all over Germany and the European continent due to the capabilities of the printing press. In the same way, when Samuel Morse and his assistant Alfred Vail finished developing the telegraph in the 1840s, the United States government gave them funding to test their telegraph between Washington D.C. and Baltimore. The first telegraph that was successfully transmitted contained the phrase "What hath God wrought (Morse Code)." Hence, these two communication technologies were first adapted to the Church and she has always taken advantage of the possibilities provided by the media. The thrust of this paper, therefore, is that the Nigerian Church has a responsibility to adapt the gospel to reach young people, and to do that, she must engage them effectively, even via social media platforms.

The thrust, therefore, is to become a people of praxis like Jesus. Kritzinger ${ }^{17}$ posits that praxis is deeper than mere practice or action; it encapsulates "action which is collective, transformative and that integrates thinking and acting, praying and working". In this way, the gap between the message of the Church and the promises and expectations of young people could be bridged. This is the only way to retain the youth in the Church and reach out to the street youth: by making a deliberate effort. Yet, what is lacking for many young people today is the compassion, truth and stability that are evident in the person of Jesus Christ and in the outreach mandate of the Church. Consequently, the Church's ministry towards the youth is cut out for her: We must engage young people in the arena of social media and guide them towards the right values - or risk losing them.

In conclusion, the church in Nigeria appears to be sleeping through the social media revolution. Notably, the effect of the Church's activities and programmes on social media is minimal, bordering on total insignificance, since she is yet to establish a meaningful presence in the world of social media. Even though social media promote hyper-individualism and an over-reliance on entertainment - qualities that undermine the spiritual goals of the Church - when engaged correctly, however, the church can enhance her message and mission among young people using social media. In fact, conventional wisdom suggests that social media can be an effective tool for the Church and youth ministries in Nigeria since they currently provide the most cost efficient and effective forms of outreach, surpassing radio and television.

\section{REFERENCES}

[1] Africa Practice. "Social Media Landscape in Nigeria." Last modified 2014. Accessed 16 June 2016. http://www.africapractice.com/wp-content/uploads/2014/04/Africa-PracticeSocial-Media-Landscape-Vol1.pdf

[2] Bartlett, J., Krasodomski-Jones, A., Daniel, N. Fisher, A. and Jesperson, S. "Social Media for Election Communication and Monitoring in Nigeria" (prepared by Demos for the Department for International Development). Last modified 2015. Accessed 16 June 2016. http://www.demos.co.uk/wp-content/uploads /2015 /11/Social-Media-in-Nigerian-Election.pdf

${ }^{16}$ Markley, "Effects of New Media."

17 J. N. J. Kritzinger, “A Question of Mission, a Mission of Questions: Who do you say that I am?" (Mk 8:29), Missionalia 30(1) (2002): 149. 
[3] Berry, R. “Older People and the Internet: Towards a 'System Map' of Digital Exclusion.” International Longevity Centre, UK. Last modified 2011. Accessed 24 April 2016. http://www.ilcuk.org.uk/files/pdf_pdf_181.pdf

[4] Broadcasting Board of Governors. "Contemporary Media Use in Nigeria." Last modified 2014. Retrieved 24 April 2016. https://www.bbg.gov/wp-content/media/2014/05/Nigeria-research-brief.pdf

[5] Christakis, D. A. and Moreno, M. A. "Trapped in the Net: Will Internet Addiction become a 21st-Century Epidemic?” Paediatric Adolescent Med. 163(10) (2009):959-960.

[6] Ciboh, R. “Adult Users' Engagement and Utilisation of Social Network Sites in Nigeria.” Paper presented at the International Conference on Communication, Media, Technology and Design, Dubai, United Arab Emirates, 16-18 May 2015.

[7] Ito, M., Horst, H. and Bittani, M. "Living and Learning with New Media: Summary of Findings from the Digital Youth Project," in John D. and Catherine T. MacArthur Foundation Reports on Digital Media and Learning. Chicago, IL. Last modified 2008. Accessed 16 June 2016. http://digitalyouth.ischool.berkeley.edu/files/report/digitalyouth-TwoPageSummary.pdf.

[8] Kritzinger, J. N. J. "A Question of Mission, a Mission of Questions: Who do you say that I am? (Mk 8:29).” Missionalia 30(1) (2002): 144-173.

[9] Lenhart, A. “Teens and Sexting." Washington, DC: Pew Research Centre. Last modified 2010. Accessed 4 August 2016. http://pewinternet.org/Reports/2009/Teens-and-Sexting.aspx

[10] Markley, B. "Effects of New Media on Youth Ministry." Senior Honours Theses, Paper 126, University of Maryland, 2015.

[11] Ogunlesi, T. "How Nigerians Use Social Media.” Premium Times. September 28, 2015.

[12] Ononogbu, D. C. "The Youth and Mission in the Mainline Churches: Between Worship and Development in Nigeria." Paper presented at the International Conference on Theology and Development (ICTD) in Nigeria, March 2016.

[13] Patchin, J. W. and Hinduja, S. "Bullies move beyond the Schoolyard: A Preliminary look at Cyberbullying." Youth Violence Juv Justice. 4(2) (2006):148-169.

[14] Wallace, K. “28 Internet Acronyms every Parent should know.” Last modified 9 January 2015. Accessed 9 January 2016. http://edition.cnn.com/2014/12/08/living/internet-acronyms-every-parent-should-know/

\section{AUTHORS' BIOGRAPHY}

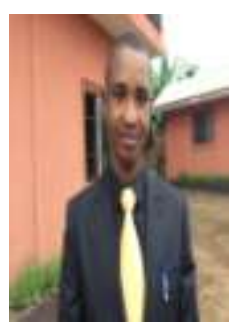

David C. Ononogbu studied religion and society (sociology of religion) at the University of Nigeria. In 2005 and 2010 respectively, he earned his Master's and Ph.D degrees studying the youth, unemployment and the social responsibility of the church in Nigeria. He has researched widely and written extensively on the youth and youth-related issues and challenges in Nigeria, where he continues to research into the perception of the church on its role in addressing dysfunction among young people and the social issues confronting them. Currently, his interest lies in understanding the theological underpinnings of youth engagement or lack thereof by the church in Nigeria, amidst the pressure of global and local forces. David serves on the faculty of the University of Nigeria where he teaches the principles and models of contemporary youth profiling, peace and conflict and the basic and ethical principles of counselling

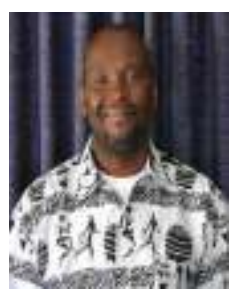

Nathan H. Chiroma is a senior lecturer at Pan Africa Christian University. He holds a PhD in Practical Theology from the University of Stellenbosch in South Africa.

Citation: David C. Ononogbu (Ph.D), Nathan Chiroma (Ph.D). “ Social Media and Youth Ministry in Nigeria: Implications and Christological Thrust" International Journal of Humanities Social Sciences and Education (IJHSSE), vol 5, no. 1, 2018, pp. 48-54. doi: http://dx.doi.org/10.20431/2349-0381.0501008.

Copyright: () 2018 Authors. This is an open-access article distributed under the terms of the Creative Commons Attribution License, which permits unrestricted use, distribution, and reproduction in any medium, provided the original author and source are credited. 